Transactions of the American Fisheries Society, 1991, Volume 120, Issue 2, Pages 230-246.

ISSN: (Print 0002-8487) (Online 1548-8659)

DOI: 10.1577/1548-8659(1991)120<0230:FCAGOT>2.3.CO;2

http://www.fisheries.org

http://afsjournals.org/loi/fitr

http://afsjournals.org/doi/pdf/10.1577/1548-8659\%281991\%29120\%3C0230\%3AFCAGOT\%3E2.3.CO\%3B2

(C) 1991 American Fisheries Society 


\title{
Food Consumption and Growth of Three Esocids: Field Tests of a Bioenergetic Model
}

\author{
David H. Wahl' and Roy A. Stein \\ Department of Zoology and Ohio Cooperative Fish and Wildlife Research Unit ${ }^{2}$ \\ The Ohio State University \\ 1735 Neil Avenue, Columbus, Ohio 43210, USA
}

\begin{abstract}
We quantified diet and compared field estimates of growth and daily ration with predictions from a bioenergetic model for young-of-year muskellunge Esox masquinongy, northern pike $E$. lucius, and tiger muskellunge $E$. masquinongy $\times E$. lucius introduced into five Ohio reservoirs. Gizzard shad Dorosoma cepedianum dominated esocid diets (77-97\% by weight) through autumn but were absent by spring. Diets in late autumn and spring included sunfishes Lepomis spp. and brook silversides Labidesthes sicculus. Northern pike and tiger muskellunge grew faster than muskellunge through the first year. Food consumption was highest for tiger muskellunge, followed by northern pike, then muskellunge. Growth rates and rations were highest immediately after stocking, declining through autumn to their lowest levels in December and spring. A bioenergetic model underestimated final mass by a factor of two to three for all esocids; predictions for food consumption were better than those for growth but still overestimated observed values by $39-52 \%$. Neither behavioral thermoregulation nor incorporation of seasonal energetic content of prey altered predictions (maximum of $2 \%$ increase). In contrast, adjustments in metabolic rates to account for differences in season and temperature substantially improved model predictions. Size-selective mortality did not account for the inaccuracies in model predictions. Conversion efficiencies (39-63\%) exceeded those previously measured for esocids fed maximum rations, suggesting that model variables should be determined for a range of ration levels. Though used extensively, the predictions of bioenergetic models should not be accepted until the models have been subjected to additional field verification.
\end{abstract}

Bioenergetic models have important applications in both ecology and fisheries biology. These mathematical models incorporate information on body size and temperature to evaluate relations between ration and growth. As such, they are powerful tools, providing insight into the effect predators have on their prey. In ecological studies, bioenergetic models are useful in evaluating the relative roles of predation and competition in structuring communities (Stewart et al. 1981). In fisheries biology, they can provide estimates of total annual predation on prey populations (Stewart et al. 1981), carrying capacity of prey populations for introduced predators (Johnson et al. 1988), and pollutant accumulation by fish (Norstrom et al. 1976).

Though bioenergetic models have been developed for a wide range of taxa (see Rice and Coch-

\footnotetext{
' Present address: Center for Aquatic Ecology, Illinois Natural History Survey, and Department of Ecology, Ethology, and Evolution, University of Illinois, 607 East Peabody Drive, Champaign, Illinois 61820 , USA.

2 The Unit is sponsored jointly by the United States Fish and Wildife Service, the Ohio Department of Natural Resources, The Ohio State University, and the Wildlife Management Institute.
}

ran 1984 for a review), including a variety of fishes (Kitchell et al. 1977; Stewart et al. 1981; Diana 1983; Rice et al. 1983; Stewart et al. 1983), they have not been adequately field-tested. Few evaluations have been attempted because labor-intensive estimates of daily ration are required. Underlying these models is the assumption that the laboratory-derived variables (as functions of temperature and mass) approximate field values. When bioenergetic models have been evaluated, however, workers have generated mixed results, including both poor fits (Diana 1983; Minton and McLean 1982; Boisclair and Leggett 1989) and good fits (Rice and Cochran 1984; Beauchamp et al. 1989) between field observations and model predictions. The most thorough statistical evaluation of a bioenergetic model found excellent correlations between observed and predicted growth for largemouth bass Micropterus salmoides (Rice and Cochran 1984). Despite the widespread use of these models and their potential for generating management insight (Kitchell and Breck 1980; Stewart et al. 1981; Johnson et al. 1988), additional, rigorous, independent field tests are necessary before their predictions can be accepted with confidence. In particular, additional assessments of growth and ration in juvenile fishes are re- 
quired, because previous work evaluated only adults.

To accomplish these tests, laboratory-derived estimates of food consumption and metabolism as functions of body mass and temperature are required, such as those made for young-of-year northern pike Esox lucius, muskellunge $E$. masquinongy, and their hybrid, tiger muskellunge $E$. lucius $\times E$. masquinongy, by Bevelhimer et al. (1985). Physiological differences related to temperature and perhaps associated with differences in geographic range (Crossman 1978) led to simulated-growth differences among the three taxa. In simulations, northern pike grew larger than muskellunge in a cool lake, but smaller than muskellunge in a warm lake. Combined effects of ration and temperature allowed tiger muskellunge to grow faster than their parents in all simulations. Based on bioenergetic considerations, Bevelhimer et al. (1985) concluded that tiger muskellunge should outgrow northern pike and muskellunge under most thermal regimes.

Herein, we have quantified growth and food consumption of tiger muskellunge, muskellunge, and northern pike after their introduction into three shallow, relatively small ( $<90$ hectares; Table 1) Ohio reservoirs (North Reservoir, Summit County: Madison Reservoir, Madison County; Kokosing Reservoir, Knox County) over 3 years and five stocking events. We assessed how temperature and ration interact to determine growth in esocids. With these data, we explicitly tested bioenergetic model predictions (Bevelhimer et al. 1985) for these three taxa, evaluated model limitations, and suggested improvements.

\section{Methods}

We quantified growth and food consumption of muskellunge, northern pike, and tiger muskellunge after equal numbers and sizes $(145,180$, or $205 \mathrm{~mm}$ ) of each taxon were stocked into three Ohio reservoirs during a 3-year period (Table 1). All esocids were reared at Ohio Division of Wildlife fish hatcheries. Tiger muskellunge were reared in troughs and fed a dry pellet diet, whereas muskellunge and northern pike were raised on fathead minnows Pimephales promelas in ponds. To permit close monitoring of growth, parent species were transferred to troughs 1 month before stocking. Esocids were counted and 100 fish were measured (total length, nearest $1 \mathrm{~mm}$ ) and weighed (nearest $0.1 \mathrm{~g}$ ) the day before they were stocked (Table 1). We collected esocids by electroshocking the en- tire perimeter of each reservoir weekly during the first month after stocking and every 2 weeks thereafter through December and again in spring. We attempted to capture at least 20 individuals per taxon on each sample date; all captured esocids were measured (total length, $1 \mathrm{~mm}$ ) and weighed $(0.1 \mathrm{~g})$. Reservoir water temperatures were monitored continually with recording thermographs at a depth of $1 \mathrm{~m}$, the approximate depth at which esocids were captured. We estimated food consumption at monthly intervals, beginning $10 \mathrm{~d}$ after stocking, using esocids collected every $3 \mathrm{~h}$ for $24 \mathrm{~h}$. Stomach contents were recovered by pulsed gastric lavage (Foster 1977) and were frozen. All prey were identified to species; partially digested fish were identified from structures resistant to digestion. Those fish that could not be identified $(<3 \%)$ because of advanced digestion were eliminated from the analysis. Prey length was recorded as total, standard, or backbone (1 $\mathrm{mm})$, depending on stage of digestion, and prey were weighed $(0.01 \mathrm{~g})$. Prey weight at ingestion was then back-calculated by use of length-weight relationships (Table 2). Fish used to establish these relationships were collected by seine during each month on days when electrofishing samples were taken. Total length, standard length $(1 \mathrm{~mm})$, and weight $(0.01 \mathrm{~g})$ were measured, then the vertebral column was removed and measured $(1 \mathrm{~mm})$.

Digestion experiments. - In the laboratory, we estimated digestion rates for tiger muskellunge $(210-270 \mathrm{~mm})$ at six temperatures $(5,10,15,20$, 25 , and $\left.30^{\circ} \mathrm{C}\right)$ and for three sizes of prey $(0.7-1.1$ g, 1.7-2.3 g, and 3.0-3.7 g). Frozen gizzard shad Dorosoma cepedianum that had been collected from Ohio reservoirs were thawed rapidly and weighed $(0.01 \mathrm{~g})$. Each esocid, acclimated to test temperatures for 2 weeks. was allowed to eat a single gizzard shad. For each temperature and prey size, we sampled tiger muskellunge at five or six cqually spaced time-intervals (10 fish/interval), beginning $15 \mathrm{~min}$ after feeding. To include the full range of variability (including fish that digested food most quickly), we ended experiments before any fish emptied its stomach. Truncating the experiments avoids the bias caused by attempts to fit data constricted by the $\mathrm{x}$-axis (Olson and Mullen 1986). Partially digested gizzard shad were recovered from esocids by gastric lavage, then were blotted dry and weighed $(0.01 \mathrm{~g})$. We fit these data to linear, exponential, and square-root models. The linear model provided the best fit of the data based on goodness-of-fit test, lack-of-fit test, and residual analysis (Neter et al. 1983) as 
TABLE 1.-Location, date, number, and size of tiger muskellunge (TM), northern pike (NP), and muskellunge (M) stocked into three Ohio reservoirs. Mean length (nearest $1.0 \mathrm{~mm}$ ) and weight (nearest $0.1 \mathrm{~g}$ ) for each taxon were based on a sample $(N=100)$ measured the day before stocking (from Wahl and Stein 1989b); CI is confidence interval.

\begin{tabular}{|c|c|c|c|c|c|c|c|c|}
\hline \multirow{2}{*}{$\begin{array}{l}\text { Reservoir } \\
\text { (hectares) }\end{array}$} & \multirow[b]{2}{*}{ Stocking date } & \multirow{2}{*}{$\begin{array}{l}\text { Num- } \\
\text { ber of } \\
\text { each } \\
\text { taxa }\end{array}$} & \multicolumn{3}{|c|}{ Total length $\pm 95 \% \mathrm{Cl}$} & \multicolumn{3}{|c|}{ Wet weight $\pm 95 \% \mathrm{CI}$} \\
\hline & & & TM & NP & $\mathbf{M}$ & TM & NP & $\mathbf{M}$ \\
\hline $\begin{array}{l}\text { North (89) } \\
\text { Kokosing (46) } \\
\text { North } \\
\text { Madison (40) } \\
\text { North }\end{array}$ & $\begin{array}{l}29 \text { Aug } 1983 \\
9 \text { Aug } 1984 \\
4 \text { Sep } 1984 \\
29 \text { Jul } 1985 \\
26 \text { Aug } 1985\end{array}$ & $\begin{array}{l}1,150 \\
1,150 \\
3,000 \\
1,000 \\
2,150\end{array}$ & $\begin{array}{l}183 \pm 3.0 \\
145 \pm 2.4 \\
177 \pm 2.2 \\
147 \pm 2.8 \\
208 \pm 4.5\end{array}$ & $\begin{array}{l}145 \pm 2.5 \\
179 \pm 3.5 \\
143 \pm 1.7 \\
205 \pm 4.7\end{array}$ & $\begin{array}{l}180 \pm 3.9 \\
147 \pm 4.5 \\
179 \pm 4.2 \\
144 \pm 3.0 \\
205 \pm 3.9\end{array}$ & $\begin{array}{l}29.0 \pm 1.6 \\
12.8 \pm 0.7 \\
24.4 \pm 1.1 \\
13.9 \pm 1.0 \\
44.3 \pm 2.7\end{array}$ & $\begin{array}{l}11.2 \pm 0.8 \\
30.7 \pm 1.9 \\
14.7 \pm 0.8 \\
44.6 \pm 3.6\end{array}$ & $\begin{array}{l}24.6 \pm 1.9 \\
11.4 \pm 1.3 \\
23.9 \pm 1.9 \\
11.8 \pm 1.0 \\
39.4 \pm 2.6\end{array}$ \\
\hline
\end{tabular}

$$
\begin{aligned}
Y= & 0.2746+0.0083(\mathrm{TI})-0.0066(T) \\
& -0.0045(T)(\mathrm{TI})+0.7635(W) \\
& -0.0047(W)(\mathrm{TI}) \quad r^{2}=0.93
\end{aligned}
$$

$Y$ is the weight of partially digested prey $(\mathrm{g}), \mathrm{TI}$ is the time since ingestion (h), $T$ is the temperature $\left({ }^{\circ} \mathrm{C}\right)$, and $W$ is the back-calculated prey weight $(\mathrm{g})$ at ingestion (stepwise linear regression, $P<0.001$; SAS 1985). The linear model has been justified on a physiological basis for fish feeding on large, single, high-energy-content prey (Jobling 1987), and it agrees with empirical evidence for other piscivorous predators (Hunt 1960; Swenson and Smith 1973; Olson and Mullen 1986). This model adequately described gastric evacuation in esocids from the first interval sampled ( $15 \mathrm{~min}$ ) until complete evacuation. However, rapid weight loss by prey during the early stages of digestion yielded intercepts $(\mathrm{TI}=0)$ less than the initial prey weights.
As a result, gastric evacuation was estimated by linear interpolation for the time-intervals between ingestion and $15 \mathrm{~min}$. Preliminary data at two temperatures and one prey size suggested that the three esocids did not differ in gastric evacuation rates (D.H.W., unpublished).

Food consumption estimates. - We estimated daily ration of esocids by a modification of Swenson and Smith's (1973) equation. We chose this method over others (Elliott and Persson 1978; Nakashima and Leggett 1978; Diana 1979) because it incorporates information on fish size and food size and does not require continuous feeding through the day (Mann 1978). Swenson and Smith (1973) assumed similar digestion rates for a range of prey sizes. To estimate daily ration more accurately, we modified their original equation by calculating digestion rates individually for each prey item. All remaining steps in the calculation

TABLE 2. - Linear regression equations ( $\left.\log _{e} Y=\beta_{0}+\beta_{1} \log _{e} X\right)$ describing the relation between wet weight ( $Y$, in g) and length $(X$, in $\mathrm{mm})$ for six species of prey fish coltected from North, Kokosing, and Madison reservoirs in

\begin{tabular}{|c|c|c|c|c|c|c|}
\hline Prey species & $N$ & $\begin{array}{l}\text { Total length } \\
\text { (range, } \mathrm{mm} \text { ) }\end{array}$ & $\begin{array}{l}\text { Length } \\
\text { type }\end{array}$ & $\begin{array}{c}\text { Intercept }\left(\beta_{0}\right) \\
\pm 95 \% \mathrm{CI}\end{array}$ & $\begin{array}{l}\text { Slope }\left(\beta_{1}\right) \\
\pm 95 \% \mathrm{Cl}\end{array}$ & $R^{2}$ \\
\hline Gizzard shad & 193 & $23-110$ & $\begin{array}{l}\text { TL } \\
\text { SL } \\
\text { BL }\end{array}$ & $\begin{array}{l}-12.25 \pm 0.02 \\
-11.72 \pm 0.02 \\
-10.18 \pm 0.02\end{array}$ & $\begin{array}{l}3.17 \pm 0.00 \\
3.23 \pm 0.01 \\
2.99 \pm 0.01\end{array}$ & $\begin{array}{l}0.99 \\
0.98 \\
0.97\end{array}$ \\
\hline Bluegill & 197 & $16-104$ & $\begin{array}{l}\text { TL } \\
\text { SL } \\
\text { BL }\end{array}$ & $\begin{array}{r}-12.08 \pm 0.01 \\
-11.28 \pm 0.01 \\
-9.78 \pm 0.01\end{array}$ & $\begin{array}{l}3.29 \pm 0.00 \\
3.28 \pm 0.00 \\
3.00 \pm 0.00\end{array}$ & $\begin{array}{l}0.99 \\
0.99 \\
0.99\end{array}$ \\
\hline Brook silverside & 63 & $35-72$ & $\begin{array}{l}\text { TL } \\
\text { SL } \\
\text { BL }\end{array}$ & $\begin{array}{l}-11.78 \pm 0.06 \\
-11.26 \pm 0.05 \\
-10.38 \pm 0.06\end{array}$ & $\begin{array}{l}2.91 \pm 0.02 \\
2.89 \pm 0.01 \\
2.81 \pm 0.02\end{array}$ & $\begin{array}{l}0.98 \\
0.98 \\
0.96\end{array}$ \\
\hline Spotfin shiner & 44 & $26-72$ & $\begin{array}{l}\text { TL } \\
\text { SL } \\
\text { BL }\end{array}$ & $\begin{array}{l}-12.25 \pm 0.06 \\
-11.84 \pm 0.06 \\
-10.77 \pm 0.06\end{array}$ & $\begin{array}{l}3.14 \pm 0.02 \\
3.21 \pm 0.02 \\
3.08 \pm 0.02\end{array}$ & $\begin{array}{l}0.99 \\
0.99 \\
0.98\end{array}$ \\
\hline Bluntnose minnow & 79 & $27-71$ & $\begin{array}{l}\text { TL } \\
\text { SL } \\
\text { BL }\end{array}$ & $\begin{array}{l}-13.96 \pm 0.14 \\
-13.35 \pm 0.13 \\
-11.18 \pm 0.14\end{array}$ & $\begin{array}{l}3.55 \pm 0.04 \\
3.57 \pm 0.04 \\
3.14 \pm 0.04\end{array}$ & $\begin{array}{l}0.87 \\
0.86 \\
0.76\end{array}$ \\
\hline White crappie & 33 & $31-72$ & $\begin{array}{l}\text { TL } \\
\text { SL } \\
\text { BL }\end{array}$ & $\begin{array}{r}-11.67 \pm 0.10 \\
-10.92 \pm 0.10 \\
-9.22 \pm 0.15\end{array}$ & $\begin{array}{l}3.00 \pm 0.03 \\
3.03 \pm 0.03 \\
2.67 \pm 0.05\end{array}$ & $\begin{array}{l}0.98 \\
0.98 \\
0.94\end{array}$ \\
\hline
\end{tabular}
Ohio. Total length (TL), standard length (SL), and backbone length (BL) equations are presented for each prey species. All regression equations were significant $(P<0.05) ; \mathrm{Cl}$ is confidence interval. 
of daily ration were as described by Swenson and Smith (1973). Food consumption for a single day (daily ration, $C\left[\mathrm{~g} \cdot \mathrm{g}^{-1} \cdot \mathrm{d}^{-1}\right]$ ) was calculated for each esocid taxon $(i)$ as

$$
C_{i}=\left(\sum_{j-1}^{n} x_{j} \div y_{j}\right) \div a
$$

$n$ is the total number of prey items ingested during a daily sample; $x$ is the weight $(\mathrm{g})$ of each prey at time of ingestion; $y$ is the total number of esocids that could have contained that prey item (based on digestion rates and time of capture); and $a$ is the mean weight $(\mathrm{g})$ of esocids collected during a sample. For comparison, we used Diana's (1979) method and found little difference in food consumption estimates. Ration also was calculated by 2-h intervals to allow evaluation of feeding periodicity.

Bioenergetic model. -As with Kitchell et al.'s (1977) model for yellow perch Perca flavescens the esocid model is

$$
G=C-(M+F+U)
$$

$G$ is the specific growth rate $\left(g \cdot g^{-1} \cdot d^{-1}\right), C$ is the specific rate of food consumption, $M$ is the specific rate of metabolism (including inactive, active, and specific dynamic action), $F$ is the specific rate of egestion, and $U$ is the specific rate of excretion. Each variable is described by mass- and temperature-dependent functions. Food consumption also can be determined as a proportion (P) of maximum consumption, which ranges from 0.0 to 1.0 .

Each model component was calculated in joules and converted to grams of biomass by use of mean energy values averaged over an annual cycle for esocids ( $1 \mathrm{~g}=4,389 \mathrm{~J} ; \mathrm{Wahl}$ and Stein 1989a) and for young-of-year gizzard shad ( $1 \mathrm{~g}=4,050 \mathrm{~J}$; Pierce et al. 1980; Strange and Pelton 1987). We used taxon-specific variables developed by Bevelhimer et al. (1985) to describe metabolism and maximum consumption as functions of mass and temperature for the three esocids $(125-210 \mathrm{~mm}$ total length); all values were as in Bevelhimer et al. (1985) with the exception of egestion and active metabolism. Bevelhimer et al. used a constant proportion of consumption (20\%), summarized by Brett and Groves (1979) for a variety of fishes, to estimate egestion. However, this value includes invertebrate-feeding fishes whose losses to egestion are higher than those of piscivorous fishes (Brett and Groves 1979). As a result, we used a $13 \%$ egestion rate developed for young-of-year northern pike (Diana 1982). Bevelhimer et al.
(1985) estimated that activity increased metabolic rate by $13 \%$ over standard metabolic rate as

$$
Y=X_{0}+X_{1} e^{q s_{1}}+X_{2} e^{q s_{2}} ;
$$

$Y$ is the increase in standard metabolic rate from activity; $X_{0}, X_{1}, X_{2}$ are the proportions of time(s) spent inactive, swimming at cruise speed, and swimming at burst speed, respectively; $q$ is a species-specific constant; and $s_{1}$ and $s_{2}$ are cruising and burst speeds $\left(\mathrm{cm} \cdot \mathrm{s}^{1}\right)$, respectively. Bevelhimer et al. (1985) used estimates for burst speed of 2 s per capture for bluegills Lepomis machrochirus and fathead minnows and a mean cruising speed of $23 \mathrm{~cm} \cdot \mathrm{s}^{-1}$ for adult northern pike determined by Diana (1980). We recalculated $Y$ with a burst-speed value of $0.9 \mathrm{~s}$ per capture of gizzard shad by esocids (Wahl and Stein 1988) and a northern pike cruising speed adjusted for relative size ( 0.45 body lengths ' $\mathbf{s}^{-1}$; Diana 1980 ); all other components were as in Bevelhimer et al. (1985). With these values, we estimated that activity increased metabolic rate $4 \%$ rather than $13 \%$ (see above) over standard metabolic rate.

Model evaluation. - To validate the esocid bioenergetic model, we compared the observed and predicted values for body mass and food consumption. First, model predictions of body mass were made based on daily estimates of food consumption and temperature; the estimates of daily consumption were determined by linearly interpolating between field observations. Second, model predictions of food consumption were made for time intervals corresponding to monthly field measurements of body mass. Predicted values of food consumption were compared with mean field values for corresponding intervals. As suggested by Rice and Cochran (1984) in their evaluation of a largemouth bass bioenergetic model, we used three statistical methods to compare model predictions with observed values. First, we compared multiple measurements of mass through time with model predictions by use of a lack-of-fit test (Neter et al. 1983). Second, errors in the model for predicting both mass and food consumption were evaluated by decomposition of mean square error (MSE) (Theil 1961) as

$$
\begin{aligned}
\mathrm{MSE} & =(1 / n) \sum_{i=1}^{n}\left(P_{i}-A_{i}\right)^{2} \\
& =(\bar{P}-\bar{A})^{2}+\left(S_{P}-r S_{A}\right)^{2}+\left(1+r^{2}\right) S_{A}{ }^{2} \\
& =Z+S+R ;
\end{aligned}
$$

$n$ is the number of paired observations; $P_{i}$ and $A_{t}$ are predicted and actual data, respectively; $\bar{P} . \bar{A}$. 
$S_{P}$, and $S_{A}$ are means and standard deviations of $P_{i}$ and $A_{i}$; and $r$ is their correlation coefficient. In least-squares regression of actual $\left(A_{i}\right)$ on predicted $\left(P_{i}\right)$ values, the mean square error represents the variance around the $1: 1$ line; $Z$ is the mean component or bias due to differences in means of predicted and actual values, $S$ is the slope component or the error resulting from the slope deviating from unity, and $R$ is the residual component or the proportion of mean square error due to random error. Values of $Z=0, S=0$, and $R=1$ indicate that errors are not systematic. We evaluated the systematic errors of $Z$ and $S$ by a regression of observed on predicted values. We used Bonferroni joint confidence intervals to test the null hypothesis that regression variables have an intercept of 0 and a slope of 1 (Neter et al. 1983); when the joint hypothesis was rejected, separate tests for the slope and the difference between the means were completed (Rice and Cochran 1984). Finally, we used the index $k$ (a number greater than 1), developed by Leggett and Williams (1981), as

$$
k=\frac{1+\sqrt{\frac{1}{n} \sum_{i=1}^{n}\left[\left(1-\frac{y_{i}}{x_{i}}\right) /\left(1+\frac{y_{i}}{x_{i}}\right)\right]^{2}}}{1-\sqrt{\frac{1}{n} \sum_{i=1}^{n}\left[\left(1-\frac{y_{i}}{x_{i}}\right) /\left(1+\frac{y_{i}}{x_{i}}\right)\right]^{2}}}
$$

$x_{1}, x_{2}, \ldots, x_{n}$ represent the model predictions, and $y_{1}, y_{2}, \ldots, y_{n}$ the corresponding observed values. This index is interpreted as the model predictions being within a factor of $k$ of actual observations. Statistically, the index indicates that the model is accurate to a factor of $k$ if about $68 \%$ of observed values fall between $1 / k$ and $k$ times the corresponding predicted values (Leggett and Williams 1981).

\section{Esocid Diets}

Analysis of diet by number and weight yielded similar conclusions (chi-square, $P=0.45$ ); thus, only prey-weight data are presented. Diets of esocids varied among reservoirs; however, years were combined for esocids in North Reservoir because diet composition among taxa did not differ (chisquare, $P=0.32$ ). In autumn, gizzard shad dominated diets in North Reservoir, followed in decreasing order of importance by Lepomis spp. (primarily bluegills), brook silversides Labidesthes sicculus, spotfin shiners Notropis spilopterus, and largemouth bass (Table 3). Esocid food habits could not be assessed beyond the first month after stocking in Kokosing and Madison reservoirs because esocid survival was extremely low (Wahl and Stein 1989b). Esocid diets in these reservoirs also included gizzard shad $(65-97 \%$ by weight) and Lepomis spp. (0-27\%), with lesser quantities of bluntnose minnows Pimephales notatus (1-2\%) and white crappies Pomoxis annularis (8-27\%) in Kokosing and Madison reservoirs, respectively. Though esocid diets were consistently dominated by gizzard shad in autumn, feeding habits were more variable in spring. Gizzard shad became less important during December through spring as they reached sizes invulnerable to predation and as their abundance declined (Wahl and Stein 1989a). In March in North Reservoir, gizzard shad were still present in esocid diets (up to $44 \%$ ), whereas in April they were replaced by centrarchids, darters, percids, and invertebrates (Table 3). Empty stomachs were common (30-82\%) and typically prevalent immediately after stocking and in spring (Table 3).

\section{Growth and Food Consumption}

Seasonal growth was similar for all esocids; individuals grew rapidly during autumn but slowly over winter (Figures 1,2). Growth was highest in 1984 and 1985 for northern pike, followed by tiger muskellunge and muskellunge (Figure 2; analysis of covariance [ANCOVA], homogeneity of slope, $P<0.001$ ), but was similar for tiger muskellunge and muskellunge in 1983 (Figure 1; ANCOVA, homogeneity of slope, $P=0.11$ ). Because stocking weights were higher (by 21\%) for northern pike than for the other taxa in 1985 (ANCOVA, homogeneity of intercept, $P=0.001$ ), we also compared relative growth rates $\left(g \cdot g^{-1} \cdot d^{-1}\right)$. These rates were similar among all three taxa during three monthly intervals (Table 4; analysis of variance [ANOVA], $F=1.64$, df $=2,17, P=0.27$ ), but they declined dramatically through autumn for all three taxa (ANOVA, $F=32.22, \mathrm{df}=2,17, P=$ 0.0006 ). Across all months and years, however, relative growth was higher for northern pike and tiger muskellunge than for muskellunge (Table 4; ANOVA, $F=6.95$, df $=2,4, P=0.05$; Tukey's multiple comparisons, $P<0.05$ ).

Daily ration levels among taxa followed trends similar to growth. Across all years, food consumption was higher for tiger muskellunge than for muskellunge (ANOVA, $F=4.41$, df $=2,25$, $P=0.02$; Tukey's multiple comparisons, $P=0.04$ ); northern pike were intermediate and did not differ from either of the other taxa (Figures 3, 4). Food 
TABLE 3.-Percent of total prey weight (back-calculated weight at ingestion) for species recovered from tiger muskellunge (TM), northern pike (NP), and muskellunge (M) stomachs at North Reservoir, Ohio, $1983-1985$. Numbers of each esocid sampled are given in parentheses.

\begin{tabular}{|c|c|c|c|c|c|c|c|c|c|c|c|c|c|c|c|c|c|c|}
\hline \multirow[b]{2}{*}{ Prey } & \multicolumn{3}{|c|}{ September } & \multicolumn{3}{|c|}{ October } & \multicolumn{3}{|c|}{ November } & \multicolumn{3}{|c|}{ December } & \multicolumn{3}{|c|}{ March } & \multicolumn{3}{|c|}{ April } \\
\hline & $\underset{(611)}{T M}$ & $\begin{array}{c}\text { NP } \\
(453)\end{array}$ & $\underset{(643)}{M}$ & $\begin{array}{c}\mathrm{TM} \\
(124)\end{array}$ & $\begin{array}{c}\text { NP } \\
(216)\end{array}$ & $\underset{(201)}{M}$ & $\begin{array}{c}\mathrm{TM} \\
(102)\end{array}$ & $\begin{array}{c}\text { NP } \\
(176)\end{array}$ & $\underset{(237)}{\mathbf{M}}$ & $\begin{array}{l}\text { TM } \\
(26)\end{array}$ & $\begin{array}{l}\text { NP } \\
(62)\end{array}$ & $\begin{array}{c}M \\
(62)\end{array}$ & $\begin{array}{l}\mathrm{TM} \\
(13)\end{array}$ & $\begin{array}{c}\text { NP } \\
(87)\end{array}$ & $\underset{(33)}{M}$ & $\begin{array}{l}\text { TM } \\
(37)\end{array}$ & $\begin{array}{l}\text { NP } \\
(45)\end{array}$ & $\begin{array}{c}M \\
(55)\end{array}$ \\
\hline $\begin{array}{l}\text { Gizzard } \\
\text { shad } \\
\text { Lepomis }\end{array}$ & 93 & 88 & 90 & 95 & 92 & 97 & 77 & 80 & 89 & 74 & 42 & 71 & 34 & 44 & 0 & 0 & 0 & 0 \\
\hline $\begin{array}{l}\text { spp. } \\
\text { Brook }\end{array}$ & 5 & 7 & 7 & 4 & 4 & 2 & 9 & 15 & 5 & 12 & 23 & 17 & 36 & 12 & 6 & 25 & 8 & 17 \\
\hline $\begin{array}{l}\text { silverside } \\
\text { Spotfin }\end{array}$ & 1 & 0 & 1 & 0 & 0 & 0 & 8 & 4 & 5 & 4 & 22 & 11 & 26 & 2 & 0 & 20 & 1 & 5 \\
\hline $\begin{array}{l}\text { shiner } \\
\text { Largemouth }\end{array}$ & 0 & 0 & 2 & 0 & 0 & 0 & 0 & 0 & 0 & 3 & 0 & 0 & 0 & 1 & 2 & 6 & 0 & 12 \\
\hline bass & 0 & 3 & 0 & 1 & 2 & I & 7 & 2 & 0 & 0 & 13 & 0 & 0 & 7 & 4 & 0 & 0 & 15 \\
\hline $\begin{array}{l}\text { Other fish } \\
\text { Inverte- }\end{array}$ & 1 & 2 & 0 & 0 & 1 & 0 & 0 & 0 & 1 & 7 & 0 & 0 & 0 & 24 & 88 & 48 & 91 & 51 \\
\hline brates & 0 & 0 & 0 & 0 & 0 & 0 & 0 & 0 & 0 & 0 & 0 & 0 & 3 & 9 & 0 & 2 & 0 & 0 \\
\hline $\begin{array}{l}\text { Total weight } \\
\text { (g) }\end{array}$ & 348 & 428 & 237 & 325 & 467 & 293 & 207 & 516 & 371 & 52 & 97 & 55 & 11 & 121 & 13 & 25 & 45 & 46 \\
\hline Empty (\%) & 60 & 54 & 64 & 30 & 38 & 48 & 34 & 34 & 43 & 35 & 43 & 58 & 54 & 55 & 76 & 65 & 82 & 60 \\
\hline
\end{tabular}

consumption was highest for all esocids in August (Kokosing and Madison reservoirs; see Figure 5), declining to lowest values in December and spring.

To assess feeding periodicity, we examined food consumption over 2 -h intervals. Feeding periodicities were similar for all months and years, so we present only September data for 3 years in North Reservoir (Figure 6). Esocid food consumption was higher during some time intervals on some sampling days (chi-square, $P<0.005$ ); however, no consistent relationship existed across years or taxa. When we combined food consumption by each taxa into light and dark periods, we found no dif-

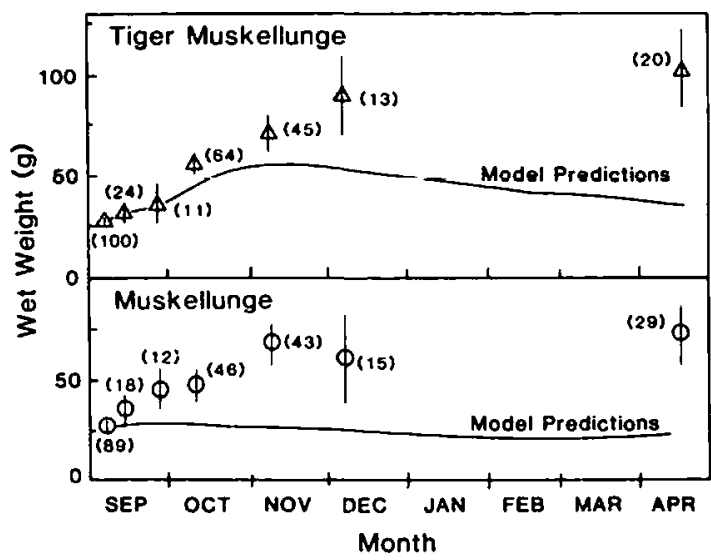

FIGURE 1.-Growth observed (open symbols) and predicted from a bioenergetic model (solid line) for tiger muskellunge and muskellunge introduced into North Reservoir, Ohio, 1983. Vertical lines are $95 \%$ confidence intervals and sample sizes are in parentheses. ference in the amount of food consumed during these two periods for any taxa or month (Figure 6 ; chi-square, $P>0.10$ ). Young-of-year esocids fed continuously through day and night.

Dividing grams of growth by grams of food consumed provided estimates of gross conversion efficiencies for the three esocid taxa. Monthly values for conversion efficiencies declined through autumn for all taxa (ANOVA, $F=42.05$, df $=2,6$, $P<0.001$; Tukey's multiple comparisons, $P<$ 0.05 ). For all three esocids, conversion efficiencies were highest in September and lowest in December; but they were higher for northern pike than for the other two taxa during November through December (ANOVA, $F=11.93$, df $=4,6, P=$ 0.005 ; Tukey's multiple comparisons, $P<0.05$ ). Across all months, conversion efficiencies were highest for northern pike, followed by muskellunge and tigcr muskcllunge (Tablc 5 ; ANOVA, $F$ $=22.45, \mathrm{df}=2,6, P=0.002$; Tukey's multiple comparisons, $P<0.05$ ).

\section{Bioenergetic Model Simulations}

We compared actual values for growth and food consumption of each esocid with predictions of Bevelhimer et al.'s (1985) bioenergetic model. Model predictions of fish mass were substantially below observed values for all three taxa in North Reservoir for all 3 years (see Figures 1, 2; lack-offit test, $P<0.001$ ). Even after samples with small numbers of fish for food consumption estimates in spring were deleted, the model still underestimated growh (lack-of-fit test, $P<0.001$ ). Suff- 


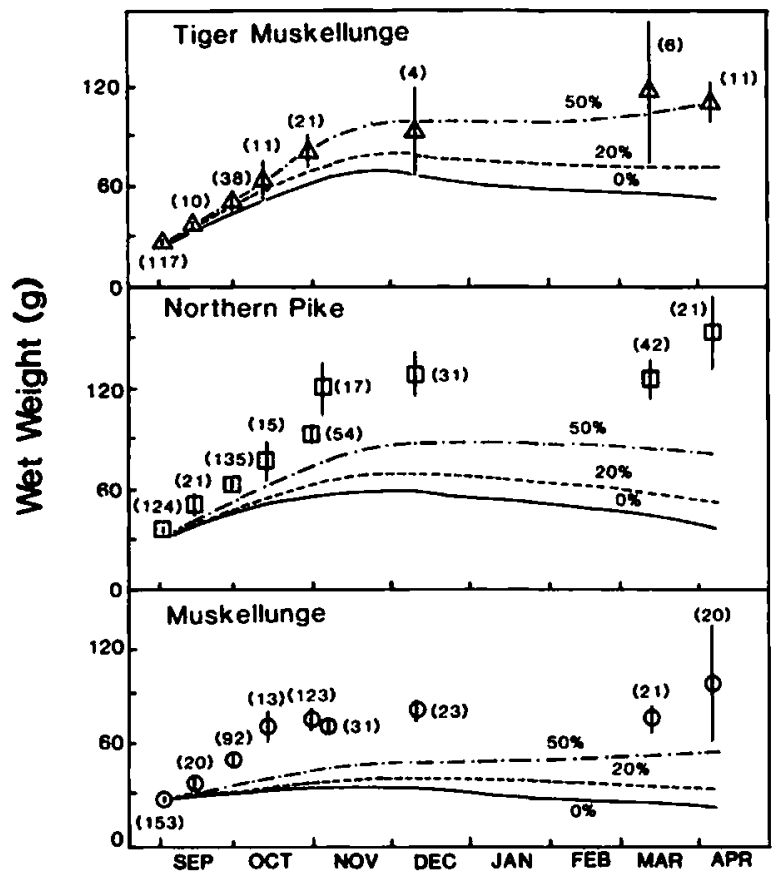

\section{Month (1984)}

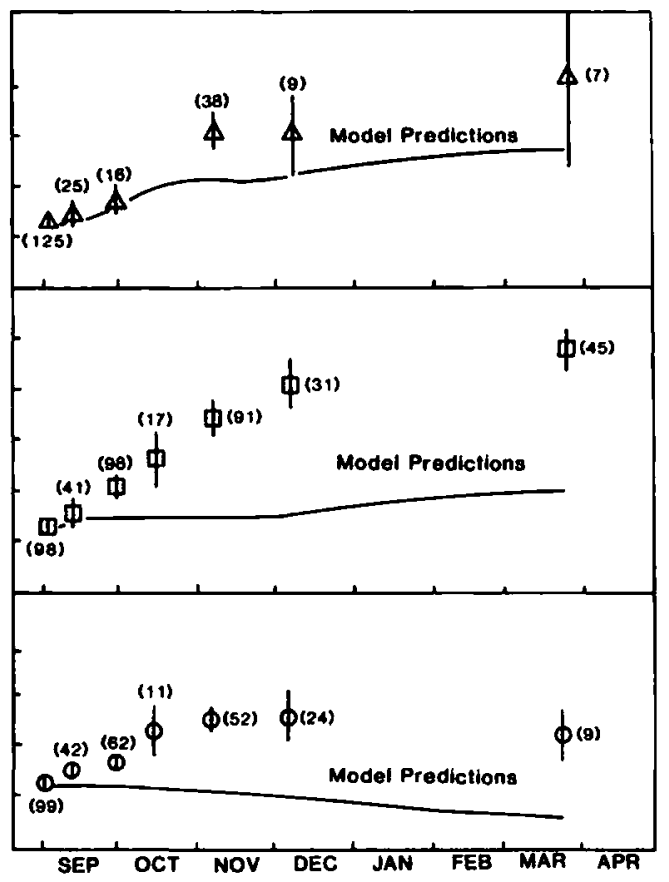

Month (1985)

Figure 2.-Growth observed (open symbols) and predicted from a bioenergetic model (solid line) for tiger muskellunge, northern pike, and muskellunge introduced into North Reservoir, Ohio, 1984-1985. Vertical lines are $95 \%$ confidence intervals and sample sizes are in parentheses. For 1984, model simulations are shown for 0 , 20 , and $50 \%$ reductions in metabolic rates to account for potential bias for seasonal, as well as temperature, effects on these estimates.

TABLE 4. - Relative growth $\left(g \cdot g^{-1} \cdot d^{-1}\right)$ for tiger muskellunge, northern pike, and muskellunge during three monthly intervals after stocking into North Reservoir, Ohio. See Figures 1 and 2 for sample sizes. Totals represent relative growth during September through December.

\begin{tabular}{cccc}
\hline $\begin{array}{c}\text { Period } \\
\text { and } \\
\text { year }\end{array}$ & $\begin{array}{c}\text { Tiger } \\
\text { muskellunge }\end{array}$ & $\begin{array}{c}\text { Northern } \\
\text { pike }\end{array}$ & Muskellunge \\
\hline $\begin{array}{l}\text { Sep-Oct } \\
1983\end{array}$ & 0.029 & & \\
1984 & 0.039 & 0.028 & 0.033 \\
1985 & 0.012 & 0.022 & 0.026 \\
Oct-Nov & & & 0.013 \\
1983 & 0.009 & & 0.006 \\
1984 & 0.018 & 0.016 & 0.018 \\
1985 & 0.022 & 0.018 & 0.015 \\
Nov-Dec & & & \\
1983 & 0.009 & & 0 \\
1984 & 0.004 & 0.009 & 0.001 \\
1985 & 0 & 0.007 & 0 \\
Total & & & \\
1983 & 0.024 & & 0.013 \\
1984 & 0.027 & 0.026 & 0.017 \\
1985 & 0.015 & 0.023 & 0.012 \\
\hline
\end{tabular}

cient numbers of esocids remained only during the first month after stocking in Kokosing and Madison reservoirs. Low survival in these two reservoirs was caused by high losses to resident predators (Wahl and Stein 1989b). During this period, predicted and observed weights agreed closely for all three taxa in Madison Reservoir and for northern pike in Kokosing Reservoir (lack-of-fit test, $P$ $>0.05$ ), but not for tiger muskellunge and muskellunge in Kokosing Reservoir (lack-of-fit test, $P$ $<0.04)$. Though trends in predicted and observed food consumption were similar, predictions were almost always higher than field observations (see Figures 3, 4; paired $t$-test, $P<0.04$ ).

To evaluate deviations between observed and predicted values of growth and food consumption, we partitioned mean square errors resulting from regressions of actual values on predicted fish mass (Figure 7) and predicted food consumption (Figure 5). Regressions of actual on predicted mass deviated substantially from the 1:1 line. Difference in means was the largest of the systematic errors for all three taxa (Table 6); the errors were 


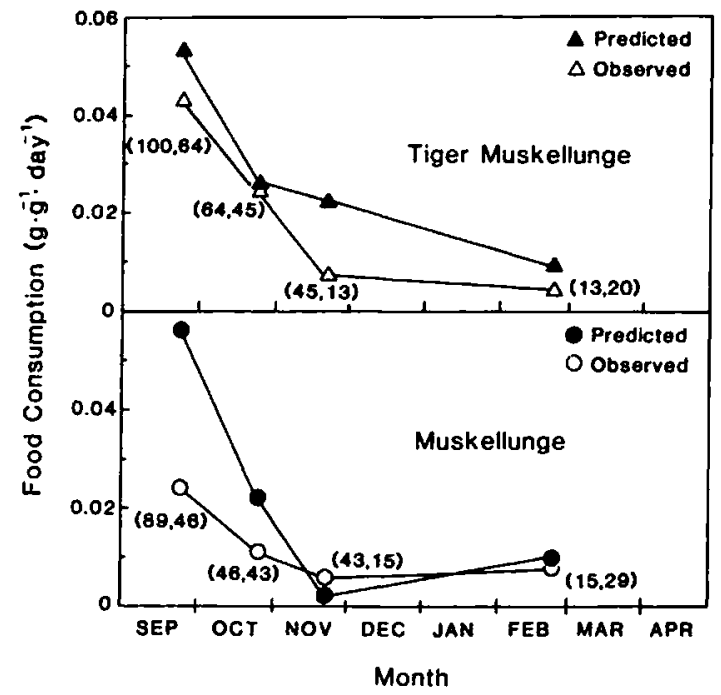

Figure 3.-Food consumption observed (averaged between sampling intervals, open symbols) and predicted from a bioenergetic model (solid symbols) for tiger muskellunge and muskellunge introduced into North Reservoir, Ohio, 1983. Predicted values are for the food consumption required to account for the growth observed between sampling intervals. Values in parentheses are sample sizes for food consumption estimates at the beginning and end of each sampling interval.

smallest for tiger muskellunge and increased dramatically for northern pike and muskellunge. Bonferroni joint confidence intervals did not include a slope of 1 and an intercept of 0 for any taxon (Table 6); for each taxon, intercepts did not equal $0(t$-test, $P<0.001)$ and predicted means were less than observed values (paired $t$-test, $T>$ 4.3 , df $=15-21, P<0.001)$. The index $(k)$ for mass was lowest for tiger muskellunge (1.48), followed by northern pike (1.95) and muskellunge (2.07), an indication that model predictions underestimated mass by as much as $32-52 \%$. Model predictions and actual mass were most similar immediately after stocking, with differences increasing through fall and winter. Predicted values underestimated final mass in spring by $52-71 \%(k=$ $2.10,2.99$, and 3.41 for tiger muskellunge, northern pike, and muskellunge, respectively).

Observed and predicted values for food consumption agreed more closely than those for growth. The random components of mean square error were highest for tiger muskellunge and northern pike, deviating the most from 1 for muskellunge (Table 6). Similarly, bias caused by differences in the means was lowest for tiger muskellunge and northern pike and highest for muskellunge. Bonferroni joint confidence inter- vals included slopes of 1 and intercepts of 0 for tiger muskellunge and northern pike, but not for muskellunge (Table 6). Individual tests for muskellunge indicated an intercept different from 0 ( $t$ test, $P=0.02$ ), and food consumption estimates were consistently higher for predicted than for observed values $(t$-test, $T=3.25, \mathrm{df}=15, P=0.005)$. The indices $(k)$ for food consumption followed patterns similar to those for growth - they were lowest for tiger muskellunge (1.63) and highest for northern pike (2.09) and muskellunge (2.00), indicating that food consumption was as much as $39-52 \%$ below model predictions.

Size-selective mortality could account for the inaccuracy of model predictions by increasing apparent growth. To evaluate this potential bias, we assessed esocid size distributions through time. If mortality was higher for small than for large esocids, we would expect size distributions to become skewed toward larger individuals through time. Because results were similar for all taxa and years, we present only 1984 data for muskellunge, the taxon with the greatest discrepancy between observed growth and model predictions. On all dates for which we had food consumption estimates, most $(81 \%, N=32)$ size distributions were normally distributed (test of normality, $P>0.05$ ). Initial distributions were skewed slightly towards larger sizes in 1983 and 1984 (Figure 8); however, in almost every instance (two exceptions of 24 intervals examined), distributions became skewed toward smaller individuals through time (Figure 8 ; test of skewness, $P>0.05$ ). Because mortality was slightly higher for larger than for smaller esocids, size-selective mortality cannot account for the large discrepancy between observed and simulated growth.

\section{Sensitivity Analysis}

We examined the sensitivity of simulated growth to potential errors in input variables. Because northern pike thermoregulate behaviorally (Headrick 1985), our use of water temperatures measured at $1 \mathrm{~m}$ could underestimate growth. From temperature profiles, we concluded that esocids could find temperatures \pm 1 " $\mathrm{C}$ of those at $1 \mathrm{~m}$ in North Reservoir (from the time stocking occurred until destratification occurred in mid-October). A variation of water temperature by $1^{\circ} \mathrm{C}$ only modified predicted final mass by $2 \%$. Potential errors from these sources were small relative to inaccuracies in model predictions (52-71\%).

Though we chose to interpolate linearly between monthly estimates of daily ration. feeding 

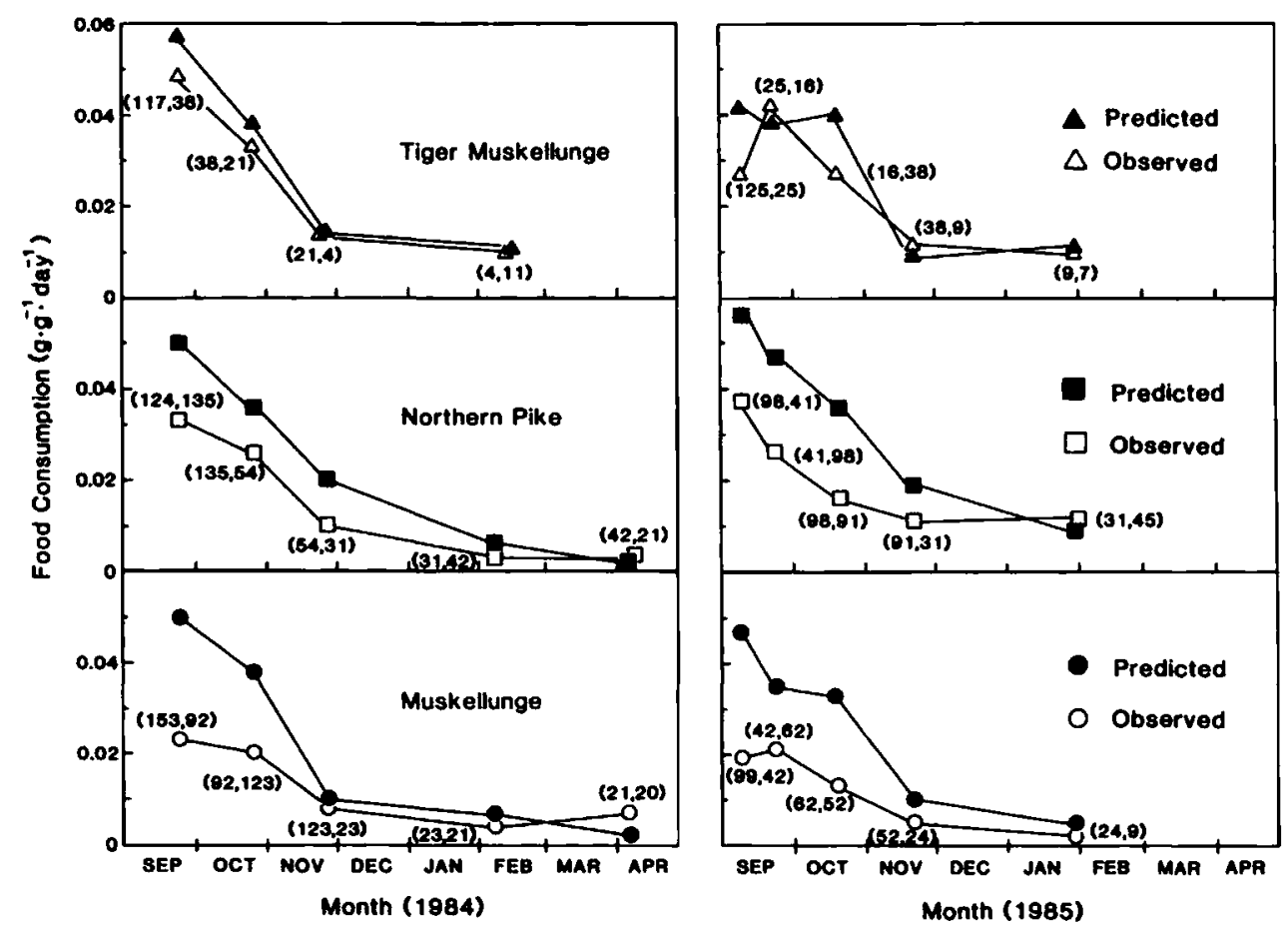

FIGURE 4. - Food consumption observed (averaged between sampling intervals, open symbols) and predicted from a bioenergetic model (solid symbols) for tiger muskellunge, northem pike, and muskellunge introduced into North Reservoir, Ohio, 1984-1985. Predicted values are the food consumption required to account for the growth observed between sampling intervals. Values in parentheses are sample sizes for food consumption estimates at the beginning and end of each sampling interval.

can be discontinuous in fishes because of sudden changes in prey availability. For comparison, we simulated discontinuous feeding by replacement of our linear interpolation with a step function (Rice and Cochran 1984). Holding food consumption constant for half the preceding and following intervals generated only a $0.9-2.5 \%$ increase in final mass.

In using mean energy values averaged annually for both predators and prey, we may have converted prey mass incorrectly into predator mass. Preliminary evidence suggests esocid energy levels are constant (Wahl and Stein 1989a) but gizzard shad energy values vary, increasing through autumn (Pierce et al. 1980; Strange and Pelton 1987). By adjusting values $(\mathrm{J} / \mathrm{g})$ of ash-free dry weight for gizzard shad from Acton Lake, Ohio (Pierce et al. 1980 ), through the use of average values for percentage moisture (78.9\%) and ash content $(21.4 \%)$ (Strange and Pelton 1987), we could estimate wetweight values $(\mathrm{J} / \mathrm{g})$ for this prey. Calculated energy levels represent only approximate seasonal values $(3.628-4,356 \mathrm{~J} / \mathrm{g}$ ) because moisture and ash con$12 \pi i$.nay vary geographically and seasonally
(Strange and Pelton 1987). With these seasonal energy values, we repeated North Reservoir simulations for 1984 (the year with largest sample sizes) and found that predicted weights in December decreased by $1.9 \%$ for tiger muskellunge, $4.2 \%$ for muskellunge, and $7.9 \%$ for northern pike. Hence, these changes cannot account for differences between observed and actual mass.

Recent evidence suggests that both temperature and season affect metabolic rate in fishes (Evans 1984). Controlling for temperature but not for season can cause errors of $20-50 \%$ in measures of standard or routine metabolism (Evans 1984). Estimates of metabolic rate used within bioenergetic models never explicitly control for season. Using the raw data of Bevelhimer (1983), we evaluated how season might have influenced metabolic experiments; we concluded that seasonal timing of experiments could have overestimated metabolism. No consistent seasonal bias occurred at temperatures of $20^{\circ} \mathrm{C}$ and higher. However, experiments at $15^{\circ} \mathrm{C}$ for all three esocids were performed in summer rather than autumn, and some experiments at $5^{\circ} \mathrm{C}$ were completed in autumn rather 


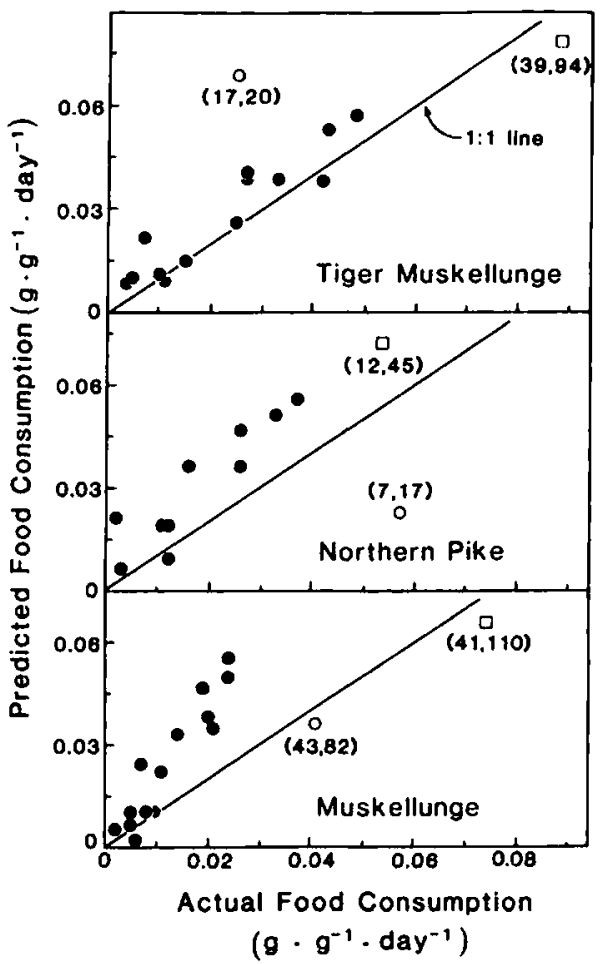

Figure 5.-Relationship between actual food consumption of tiger muskellunge, northern pike, and muskellunge and food consumption predicted from a bioenergetic model. Errors are not systematic if values fall along the 1:1 line. Solid symbols are for North Reservoir. Ohio, 1983, 1984, 1985. Open symbols represent Kokosing (squares) and Madison (circles) reservoirs, Ohio. Sample sizes are in parentheses for the latter two reservoirs.

than winter (no experiments were completed at $10^{\circ} \mathrm{C}$ ). Because these data influenced the shape of the metabolic curves from 5 to $20^{\circ} \mathrm{C}$ (water temperatures most prevalent in North Reservoir simulations), they were critical to our bioenergetic modeling. Water temperatures in Kokosing and Madison reservoirs were above $25^{\circ} \mathrm{C}$ during the first month after stocking because stocking dates were earlier (late July and early August, see Table 1) than in North Reservoir (late August and early September). To simulate the potential range of metabolic effects, we reduced metabolic rates by 20 and $50 \%$ for all esocids in North Reservoir, 1984 (see Figure 2). Adjustments were made by reducing the intercept coefficient of the metabolic rate equation ( $a_{2}$, Bevelhimer et al. 1985). These adjustments substantially improved agreement between observed mass and model predictions; however, the model still underestimated northern

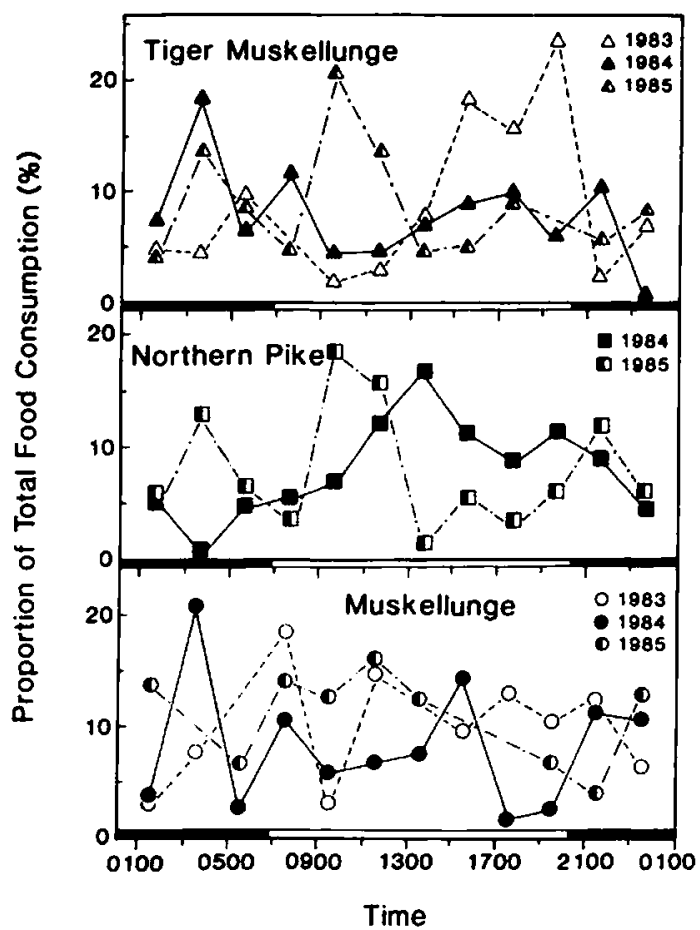

Figure 6. - Diel feeding by tiger muskellunge, northern pike, and muskellunge in September of 1983, 1984, and 1985 in North Reservoir, Ohio. Estimates for each interval were obtained by summing food consumption over 2-h time periods for $24 \mathrm{~h}$. Shaded areas on the $\mathrm{x}$-axis denote periods of darkness.

pike and muskellunge growth even when metabolic rates were reduced $50 \%$ (lack-of-fit test, $P<$ 0.001 ). Only with a $50 \%$ reduction did the model adequately predict growth for tiger muskellunge (lack-of-fit test, $P>0.5$ ). A $50 \%$ reduction in metabolic rate also substantially improved model predictions of food consumption. For all taxa, mean

TABLE 5. - Gross conversion efficiencies $(\%=100[\mathrm{~B}$ of growth $\div \mathrm{g}$ of food consumption]) for tiger muskellunge, northern pike, and muskellunge from date of stocking (iate August to early September) through December in North Reservoir, Ohio. Summing growth and food consumption across years provides an estimate of average conversion efficiency for the three taxa. See Figures 1 and 2 for sample sizes.

\begin{tabular}{cccc}
\hline Ycar & $\begin{array}{c}\text { Tiger } \\
\text { muskel- } \\
\text { lunge }\end{array}$ & $\begin{array}{c}\text { Northern } \\
\text { pike }\end{array}$ & $\begin{array}{c}\text { Muskel- } \\
\text { lunge }\end{array}$ \\
\hline 1983 & 49.6 & & 49.7 \\
1984 & 40.1 & 60.8 & 55.4 \\
1985 & 31.1 & 65.8 & 56.1 \\
Average & 39.2 & 63.1 & 53.9 \\
\hline
\end{tabular}




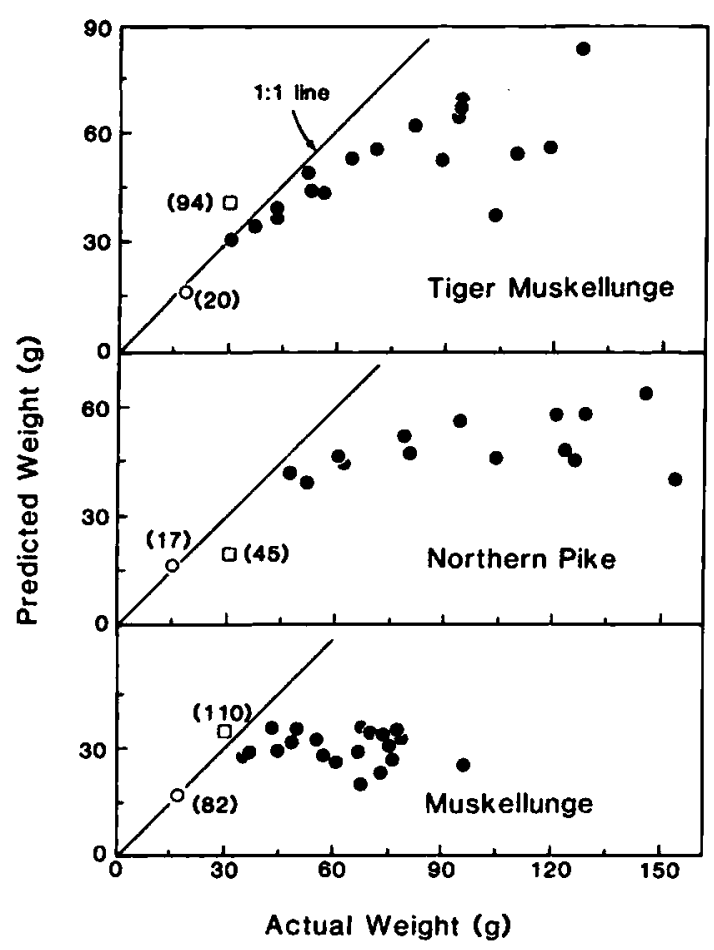

Figure 7.-Relationship between actual mass and mass predicted from a bioenergetic model for tiger muskellunge, northern pike, and muskellunge. Errors are not systematic if values fall along the 1:1 line. Solid symbols are for North Reservoir, Ohio, 1983, 1984, 1985. Open symbols are for Kokosing (squares) and Madison (circles) reservoirs, Ohio. Sample sizes are in parentheses for the latter two reservoirs.

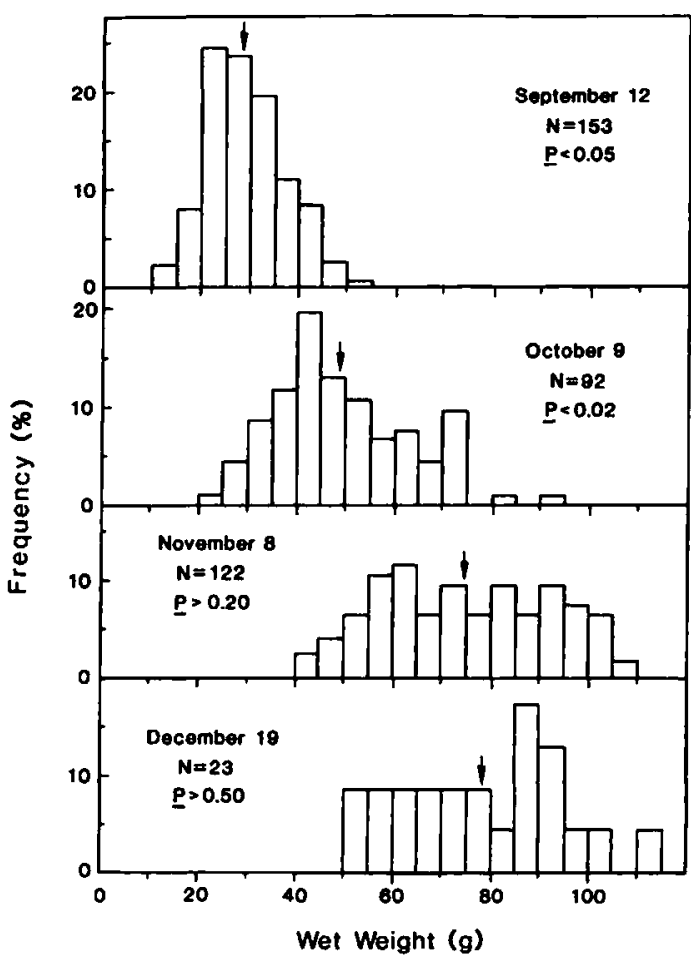

FIGURE 8.- Weight distribution of muskellunge at monthly intervals after stocking into North Reservoir, Ohio, 1984. Arrows indicate mean mass (g); $P$ values are for tests of skewness (SAS 1985).

TABl. 6. - Proportion of mean square ertor due to systematic (mean and slope) and random (residual) components for the relation between actual mass or actual food consumption and values predicted by a bioenergetic model for tiger muskellunge (TM), northern pike (NP), and muskellunge (M) after five reservoir stockings. Also, actual food consumption is compared with model predictions adjusted to account for potential bias for seasonal, as well as temperature, effects on metabolic rates ( $50 \%$ reduction in metabolic rate). Values for mean and slope components close to 0 and a random component close to 1 indicate that errors are not systematic. Bonferroni joint confidence intervals for the null hypothesis of an intercept $\left(\beta_{0}\right)$ of 0 and a slope $\left(\beta_{1}\right)$ of 1 are presented for each taxon; $C I$ is confidence interval.

\begin{tabular}{|c|c|c|c|c|c|}
\hline \multirow[b]{2}{*}{ Esocid taxa } & \multicolumn{3}{|c|}{ Sources of error } & \multirow[b]{2}{*}{$\beta_{0} \pm 95 \% \mathrm{CI}$} & \multirow[b]{2}{*}{$\beta_{1} \pm 95 \% \mathrm{CI}$} \\
\hline & Mean & Slope & Residual & & \\
\hline \multicolumn{6}{|c|}{ Mnss } \\
\hline $\begin{array}{l}\text { TM } \\
\text { NP } \\
\text { M }\end{array}$ & $\begin{array}{l}0.19 \\
0.40 \\
0.68\end{array}$ & $\begin{array}{l}0.04 \\
0.06 \\
0.01\end{array}$ & $\begin{array}{l}0.76 \\
0.54 \\
0.31\end{array}$ & $\begin{array}{l}22.38 \pm 13.18 \\
25.76 \pm 14.14 \\
28.04 \pm 8.92\end{array}$ & $\begin{array}{r}0.39 \pm 0.17 \\
0.22 \pm 0.15 \\
0.027 \pm 0.14\end{array}$ \\
\hline \multicolumn{6}{|c|}{ Food consumption } \\
\hline $\begin{array}{l}\text { TM } \\
\text { NP } \\
\text { M }\end{array}$ & $\begin{array}{l}0.06 \\
0.13 \\
0.37\end{array}$ & $\begin{array}{l}0.02 \\
0.10 \\
0.04\end{array}$ & $\begin{array}{l}0.93 \\
0.77 \\
0.59\end{array}$ & $\begin{array}{l}0.011 \pm 0.013 \\
0.015 \pm 0.020 \\
0.012 \pm 0.011\end{array}$ & $\begin{array}{l}0.874 \pm 0.386 \\
0.751 \pm 0.688 \\
0.879 \pm 0.457\end{array}$ \\
\hline \multicolumn{6}{|c|}{ Food consumption with metabolic adjustment } \\
\hline $\begin{array}{l}\text { TM } \\
\text { NP } \\
\text { M }\end{array}$ & $\begin{array}{l}0.00 \\
0.02 \\
0.01\end{array}$ & $\begin{array}{l}0.01 \\
0.05 \\
0.02\end{array}$ & $\begin{array}{l}0.99 \\
0.93 \\
0.97\end{array}$ & $\begin{array}{l}0.007 \pm 0.008 \\
0.009 \pm 0.018 \\
0.008 \pm 0.010\end{array}$ & $\begin{array}{l}0.691 \pm 0.310 \\
0.756 \pm 0.602 \\
0.710 \pm 0.394\end{array}$ \\
\hline
\end{tabular}


and slope components of MSE were close to 0 and the random components were near 1 (Table 6), suggesting that errors were not systematic. In addition, Bonferroni joint confidence intervals included slopes of 1 and intercepts of 0 for all three taxa (Table 6). With adjustments in metabolic rates to account for potential bias from completing experiments in inappropriate seasons and at different temperatures, the bioenergetic model provided good estimates of observed food consumption. Consequently, of all the variables manipulated, only reduced metabolic rate substantially improved the fit between field data and the model.

\section{Consumption: Estimating Proportion of Maximum Ration}

Rather than using field estimates of consumption, we varied the proportion of maximum consumption ( $P$, Bevelhimer et al. 1985) to fit the original model predictions to empirical field growth. Results were not significantly different among years; thus, we present data only for North Reservoir, 1984. Model predictions, based on a constant proportion of maximum consumption for each esocid through the seasons (range, 0.7-0.9), generally mimicked esocid growth in all years but overestimated observed growth through autumn (Figure 9; lack-of-fit test, $P<0.001$ ). Use of two time periods (autumn and winter) also underestimated growth during late autumn: higher $\mathbf{P}$ values were required during November through December. Division of the sampling period into three discrete time periods - early autumn (September to November), late autumn (November to December), and overwinter (December to April)was required to fit model predictions closely to observed growth (Figure 9; lack-of-fit test, $P>$ 0.05 ). Unfortunately, $P$ values exceeding 1.0 (some as high as 1.6) were required to match observed growth of tiger muskellunge and northern pike to model predictions during November to December, the single exception being tiger muskellunge in 1985 .

\section{Discussion}

\section{Esocid Diets, Food Consumption, and Growth}

Consistent with laboratory and field prey-selection experiments (Mauck and Coble 1971; Weithman and Anderson 1977; Wahl and Stein 1988), all three esocids fed predominantly on gizzard shad. Gizzard shad are preferred and are apparently more easily captured than centrarchid prey because of their morphology and lack of antipred- atory behavior (Wahl and Stein 1988). Other prey species varied by reservoir and occurred in proportion to their abundance as determined by seine (Wahl and Stein 1989a) and quadrat rotenone sampling (Johnson et al. 1988). Esocid diets diversified in late fall and spring when gizzard shad were large and least abundant.

We found no diel pattern of feeding in youngof-year esocids. No other studies of esocids have examined diel feeding periodicity. Data on activity determined by telemetry and gillnetting of adult northern pike are contradictory, indicating crepuscular and nocturnal (Lawler 1969; Casselman 1978) or daylight activity (Diana 1980). Techniques used in these studies may not have detected movements over short distances for feeding purposes. Feeding activity appears to be continuous, at least for juvenile esocids.

In our reservoirs, northern pike and tiger muskellunge grew at similar rates, but both grew faster than muskellunge. In ponds, the only other water body where all three taxa were stocked, muskellunge again grew slowest, but tiger muskellunge outgrew northern pike (Weithman and Anderson 1977). Small differences in thermal regimes between reservoirs and ponds might cause differential growth among these esocid taxa. In laboratory experiments, Bevelhimer et al. (1985) found that growth among esocids varied with temperature. For example, northern pike grew faster than tiger muskellunge at 25 and $5^{\circ} \mathrm{C}$, tiger muskellunge grew faster at $22.5^{\circ} \mathrm{C}$, and both esocids grew at similar rates at $20^{\circ} \mathrm{C}$. In contrast, we found that relative growth rates of esocids sampled at monthly intervals did not differ, but large fluctuations in temperature could have obscured differences.

Temperature and ration in fishes interact to determine growth. Daily food consumption levels were highest for tiger muskellunge, followed by northern pike and muskellunge, but average conversion efficiencies were highest for northern pike $(63 \%)$, followed by muskellunge $(54 \%)$ and tiger muskellunge (39\%). Our conversion efficiencies were higher than those cited for piscivorous fishes (see Brett and Groves 1979; Lane et al. 1979), but few estimates exist for juvenile piscivores, whose conversion efficiencies are highest. Conversion efficiencies for young-of-year esocids in laboratory experiments have varied from $42 \%$ for northern pike (Diana 1983) to $37 \%$ for muskellunge (Gammon 1963) and from 12 to $38 \%$ (depending on temperature) for all three esocids (Bevelhimer et al. 1985). As in our work, laboratory-derived conversion efficiencies declined for all esocids as wa- 


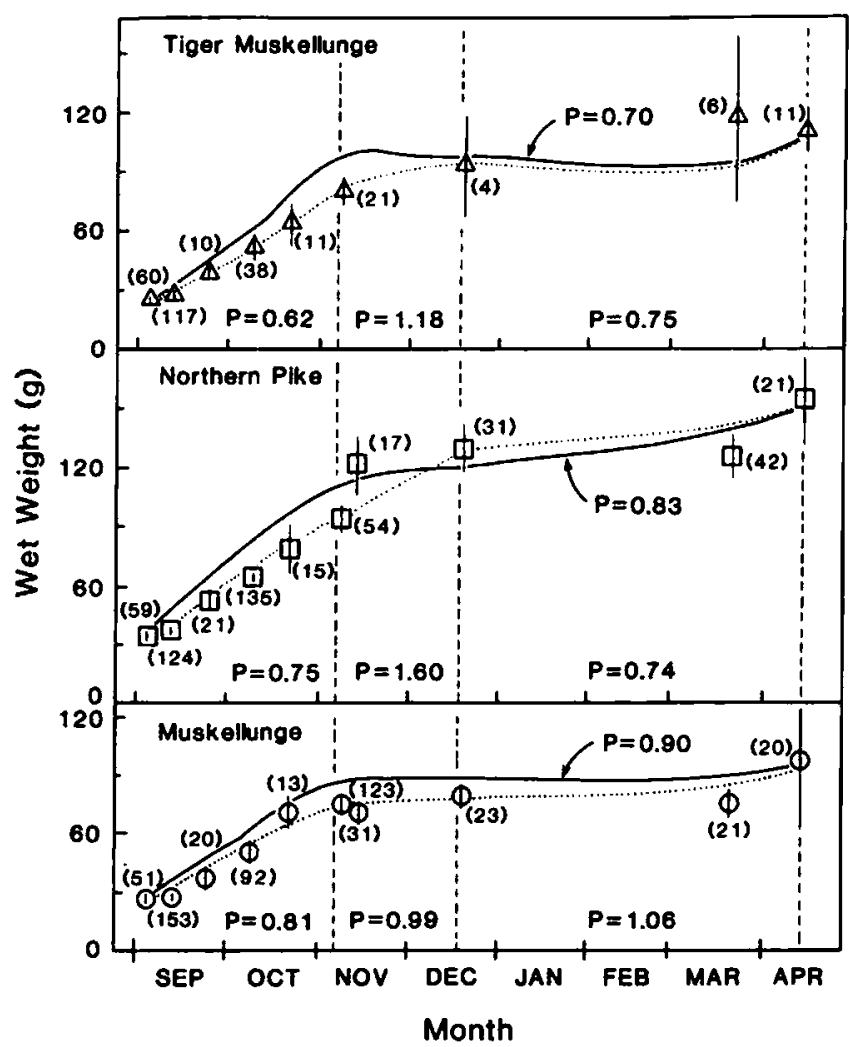

FiguRE 9.-Growth rates for tiger muskellunge, northern pike, and muskellunge predicted from a single value for proportion of maximum consumption, $P$ (solid line) and from different values for three time periods (dashed line) after introduction of these esocids into North Reservoir, Ohio, 1984. Vertical lines are $95 \%$ confidence intervals and sample sizes are in parentheses.

ter temperatures declined, with northern pike showing the highest value at the lowest temperature (near $5^{\circ} \mathrm{C}$; Bevelhimer et al. 1985); these laboratory conversion efficiencies are lower than our field values. Because conversion efficiencies often decline above some optimum ration level (Paloheimo and Dickie 1966; Kerr 1971; Warren 1971; Brett and Groves 1979), the high feeding rate of laboratory esocids (all near maximum ration) could account for the low conversion efficiencies. Although taxon-specific relationships between conversion efficiencies and ration levels in esocids are unknown, they could account for the higher than expected field growth rates.

\section{Bioenergetic Model Simulations}

The bioenergetic model of Bevelhimer et al. (1985) substantially underestimated esocid growth when run with data on rations and temperatures measured in the field. These underestimates could have resulted from errors in model inputs, such as food consumption or growth, or from errors in model variables. Our sample sizes for individual estimates of consumption and growth were large, except for some in late autumn and spring when $N$ was less than 30/taxon during 24-h samples. Because consumption estimates were based on only one sample day per month, large day-to-day variation in actual consumption could affect modeling results. However, growth and consumption among months were consistent across 3 years for all three esocids, suggesting that potential bias due to high daily variability was low.

Gear selectivity that sampled only large fish in a population, or selective mortality of small esocids, could have resulted in overestimates of esocid size and, consequently, growth rates (Cochran and Knutsen 1988). Because we sampled almost the entire littoral zone by electrofishing, a relatively nonselective sampling gear within the sizerange of the fish encountered, and because both growth and food consumption were estimated from 
the same fish, bias from gear selectivity seems unlikely. Predation by largemouth bass is a major source of mortality for stocked esocids (2-53\%; Wahl and Stein 1989b) and might be size selective; however, we have found three arguments against the hypothesis that predatory mortality is size selective. First, model predictions of growth from food consumption for tiger muskellunge, with both the highest predatory and total mortality, agreed most closely with field data. Second, even when predatory mortality was low, as in North Reservoir in 1985 ( $<2 \%$ because of large stocking size; Wahl and Stein 1989b), model predictions did not improve. Finally, growth in reservoirs was similar to growth in ponds without predators (Weithman and Anderson 1977; Gillen et al. 1981: Tomcko et al. 1984). In addition, our examination of esocid size distributions through time indicated that mortality was slightly higher for large esocids, suggesting that size-selective mortality cannot account for model underestimates of growth. Potential errors for other model input variables, notably temperature and energy content, could affect model outcomes. However, behavioral thermoregulation (Headrick 1985) increased esocid growth rates by only $2 \%$, whereas use of seasonal energy content for prey (Pierce et al. 1980; Strange and Pelton 1987) actually reduced model estimates of growth.

Having evaluated the importance of input variables, we now examine possible errors in model variables. Because single-season determinations of metabolic rates in fishes may be inadequate (Evans 1984), we adjusted metabolic rates to account for possible bias from seasonal effects. This resulted in substantial improvement in model predictions for esocids in North Reservoir, but predictions from the unadjusted model were closest to actual values for the month after stocking in Madisun and Kokosing reservoirs. Water temperatures in these last two reservoirs were above the range in which we observed possible bias due to seasonal effects. Consequently, photoperiod, temperature, and time of year should all be controlled in future laboratory determinations of metabolic rates. This control may be essential to development of reliable bioenergetic models. Values for proportion of maximum consumption greater than 1 also suggest errors in laboratory-derived estimates of variables. Laboratory experiments may have underestimated the intercept coefficient of the maximum consumption functions. Alternatively, functions regressing maximum food consumption against temperature may not accurately describc consumption at temperatures between 5 and $15^{\circ} \mathrm{C}$, the temperatures most prevalent in the field when proportions of maximum consumption exceeded 1 (e.g., no experiments were completed at $10^{\circ} \mathrm{C}$ by Bevelhimer et al. 1985). Other factors, such as stress in fish held in the laboratory, may cause errors in estimates of maximum consumption (underestimates) and metabolic rates (overestimates). To avoid these problems, fish must be acclimated to experimental conditions for several weeks, as was the case in the work by Bevelhimer et al. (1985). If present, these biases should be consistent across all temperatures and seasons; this was not the case in our model simulations.

Discrepancies between field and laboratory-derived estimates of conversion efficiencies suggest potential errors in model variables for egestion, excretion, or specific dynamic action. If conversion efficiencies decline with increasing rations, laboratory-derived estimates for these three variables, determined at maximum rations, may overestimate these losses (Healey 1972). Egestion and excretion losses vary substantially with temperature and ration in brown trout Salmo trutta (Elliott 1976). Using Elliott's (1976) data, Kitchell et al. (1977) argued that the sum of egestion and excretion remains approximately constant as a function of temperature. However, the sum of egestion and excretion decreases as ration levels decrease (Elliott 1976). In error analyses for three bioenergetic models, Bartell et al. (1986) concluded that accurate calculation of food consumption was more important than errors in egestion and excretion, because these variables are calculated as functions of consumption (a constant $20 \%$ in the esocid bioenergetic model). However, given the degree to which conversion efficiencies and egestion vary with prey type (Brett and Groves 1979), additional evaluations of the magnitude and relationship of these variables to temperature and ration in species other than brown trout would improve these model components.

Model predictions of food consumption in the field were substantially better than those for growth. Other evaluations of bioenergetic models have recommended use of fish growth to estimate rates of consumption (Kitchell et al. 1977; Stewart et al. 1983; Rice and Cochran 1984; Bartell et al. 1986), because fish growth in the field can generally be estimated accurately and precisely with relatively little effort, whereas estimates of food consumption are more difficult. We concur with these evaluations; because model inputs are easier to collect and are more reliable, predictions of food 
consumption are better than those for growth. However, errors in estimation of food consumption from growth are still high for esocid models (39-52\%), suggesting that the current model can provide only broad estimates of the potential effects of predators on prey populations. When estimates are summed over an annual cycle, resulting errors from models with these accuracy levels will be large.

A single annual value for proportion of maximum consumption would indicate that feeding rate is a function only of temperature and fish size, not of food resources (Kitchell and Breck 1980; Stewart et al. 1981). Three time periods were required to describe growth rates adequately in esocids. Model simulations with largemouth bass successfully identified intraseasonal fluctuations in food availability, with low $\mathbf{P}$ values corresponding to periods of reduced prey abundance (Rice and Cochran 1984; Stewart and Binkowski 1986). These relationships were not evident in our simulations; the highest $P$ values occurred when gizzard shad were declining in abundance and growing beyond a size vulnerable to juvenile esocids (Wahl and Stein 1989a). Reduced water temperatures that might have increased prey susceptibility accompanied high $\mathbf{P}$ values. Because gizzard shad become lethargic and exhibit reduced swimming ability below $10^{\circ} \mathrm{C}$ (Cox and Coutant 1976; Griffith 1978), they may be more vulnerable from November through spring, thus contributing to high esocid rations and $P$ values. Alternatively, esocids fed more on alternate prey during late autumn and spring and thus may have been able to maintain high proportions of maximum consumption despite declining availability of gizzard shad. Additional evaluations of the relations between prey availability and consumption are required to explain the high $P$ values.

\section{Applications of Bioenergetic Models}

Bioenergetic models have important management applications in that they are used to estimate the effect of resident and stocked predators on prey populations and to evaluate competitive interactions (Stewart et al. 1981; Johnson et al. 1988). It is imperative, however, that these models be thoroughly field tested and that the magnitude of potential errors be identified before predictions from these models are used to support management decisions. To date, model evaluations have not been encouraging, the exceptions being Rice and Cochran's (1984) success with the largemouth bass model and the evaluation by Beauchamp et al.
(1989) of the model for sockeye salmon Oncorhynchus nerka. For models that failed to describe field data adequately, several components have been suggested as the cause of errors. Boisclair and Leggett (1989) found no relationship between predicted and observed food consumption estimates in 12 populations of yellow perch and attributed errors to differences in activity among populations. Diana (1983), after reporting errors of 30$160 \%$ in predictions of growth and food consumption for adult northern pike, concluded that some budget components were in error and that field estimates of daily ration were probably inaccurate. Minton and McLean (1982) found good agreement between predicted and observed growth for saugers Stizostedion canadense from March through October but poor agreement from November through February. They concluded that either growth efficiency or active metabolism was in error. Winter metabolic rates determined during other seasons also could have caused these discrepancies (Evans 1984).

The results cited above and those presented in this paper suggest that future laboratory estimates of metabolic rates should account for both season and temperature. Additionally, relationships between conversion efficiency and ration should be quantified. Although size-selective mortality was unimportant in our work, future applications of bioenergetic models for juvenile fishes should consider this possibility. Our predictions were most accurate for tiger muskellunge, followed by northern pike and muskellunge. The current esocid bioenergetic model, without control for seasonal effects on metabolic rates, can predict growth reliably only within a factor of two to three and food consumption within a factor of two. Consequently, before the esocid model can be used widely to make management decisions, additional laboratory work and field verification will be necessary.

\section{Acknowledgments}

We thank the many individuals associated with the Aquatic Ecology Laboratory who provided volunteer and technical assistance; in particular, the efforts of D. Bryson, K. Bruner, D. Imhoff, V. Murchake, J. Miner, B. Kerans, D. Devries, S. Klosiewski, and L. Einfalt were critical to this research effort. T. Lee assisted with computer programing. Statistical support was provided by the Statistical Consulting Service, The Ohio State University. L. Einfalt drafted the figures. J. Margraf, G. Mittelbach, B. Vondracek, D. Stewart, M. Bevelhimer, J. Breck, J. Dettmers, and J. Miner 
critically reviewed the manuscript. T. Nagel (London Fish Farm) and P. Keyes (Hebron Fish Farm) provided esocids, and D. B. Apgear coordinated activities with the Ohio Division of Wildlife. This study was supported in part by funds from the Federal Aid in Fish Restoration Act under Project F-57-R. This paper is dedicated to the memory of David A. Benkowski, graduate student of DHW, who died during the final stages of the preparation of this manuscript. Dave had a strong interest in fisheries ecology and bioenergetic modeling and showed great potential in these areas.

\section{References}

Bartell, S. M., J. E. Breck, R. H. Gardner, and A. L. Brenkert. 1986. Individual parameter perturbation and error analysis of fish bioenergetics models. Canadian Journal of Fisheries and Aquatic Sciences 43:160-168.

Beauchamp, D. A., D. J. Stewart, and G. L. Thomas. 1989. Corroboration of a bioenergetics model for sockeye salmon. Transactions of the American Fisheries Society 118:597-607.

Bevelhimer, M.S. 1983. Assessing the significance of physiological differences among three esocids with a bioenergetics model. Master's thesis. Ohio State University, Columbus.

Bevelhimer, M. S., R. A. Stein, and R. F. Carline. 1985. Assessing significance of physiological differences among three esocids with a bioenergetics model. Canadian Journal of Fisheries and Aquatic Sciences 42:57-69.

Boisclair, D., and W. C. Leggett. 1989. The importance of activity in bioenergetics models applied to actively foraging fishes. Canadian Journal of Fisheries and Aquatic Sciences 46:1859-1867.

Brett. J. R., and T. D. D. Groves. 1979. Physiological energetics. Pages 279-353 in W. S. Hoar and D. J. Randall, editors. Fish physiology. Academic Press, New York.

Casselman, J. M. 1978. Effects of environmental factors on growth, survival, activity, and exploitation of northern pike. American Fisheries Society Special Publication 11:114-128.

Cochran, P. A.. and K. J. Knutsen. 1988. Error in estimation of feeding rates from changes in mean body mass. Canadian Journal of Fisheries and Aquatic Sciences 45:1494-1498.

Cox. D. K.. and C. C. Coutant. 1976. Acute cold-shock resistance of gizzard shad. Pages 159-161 in G. W. Esch and R. W. McFarlane, editors. Thermal ecology II. ERDA (Energy Research and Development Administration) Symposium Series. Technical Information Center. Oak Ridge, Tennessee.

Crossman, E. J. 1978. Taxonomy and distribution of North American esocids. American Fisheries Society Special Publication 11:13-26.

Diana, J. S. 1979. The feeding pattern and daily ration of a top camivore, the northem pike (Esox lucius). Canadian Journal of Zoology 57:2121-2127.
Diana, J. S. 1980. Diel activity pattern and swimming speeds of northem pike (Esox lucius) in Lac Ste. Anne, Alberta. Canadian Journal of Fisheries and Aquatic Sciences 37:1454-1458.

Diana, J. S. 1982. An experimental analysis of the metabolic rate and food utilization of northem pike. Comparative Biochemistry and Physiology 71A: 395-399.

Diana, J. S. 1983. An energy budget for northern pike (Esox lucius). Canadian Joumal of Zoology 61:19681975.

Elliott, J. M. 1976. Energy loss in the waste products of brown trout (Salmo trutta L.). Journal of Animal Ecology 45:56I-580.

Elliott, J. M., and L. Persson. 1978. The estimation of daily rates of food consumption for fish. Journal of Animal Ecology 47:977-991.

Evans, D. O. 1984. Temperature independence of the annual cycle of standard metabolism in the pumpkinseed. Transactions of the American Fisheries Society 113:494-512.

Foster. J. R. 1977. Pulsed gastric lavage: an efficient method of removing the stomach contents of live fish. Progressive Fish-Culturist 39:166-169.

Gammon, J. R. 1963. Conversion of food in young muskellunge. Transactions of the American Fisheries Society 92:183-184.

Gillen, A. L., R. A. Stein, and R. F. Carline. 1981 Predation by pellet-reared tiger muskellunge on minnows and bluegills in experimental systems. Transactions of the American Fisheries Society 110 : 197-209.

Griffith, J. S. 1978. Effects of low temperature on the behavior and survival of threadfin shad (Dorosome petenense). Transactions of the American Fisheries Society 107:63-69.

Headrick, M. R. 1985. Bioenergetic constraints on habitat use by northern pike (Esox lucius) in Ohio reservoirs. Doctoral dissertation. Ohio State University. Columbus.

Healey, M. C. 1972. Bioenergetics of a sand goby ( $\mathrm{Go}$ bius minutus) population. Journal of the Fisheries Research Board of Canada 29:187-199.

Hunt, B. P. 1960. Digestion rate and food consumption of Florida gar, warmouth, and largemouth bass. Transactions of the American Fisheries Society 89: 206-211.

Jobling, M. 1987. Influences of food particle size and dictary energy content on patterns of gastric evacuation in fish: test of a physiological model of gastric evacuation. Journal of Fish Biology 30:299-314.

Johnson, B. M., R. A. Stein, and R. F. Carline. 1988. Use of a quadrat rotenone technique and bioenergetics modeling to evaluate prey availability to stocked piscivores. Transactions of the American Fisheries Society 117:127-141

Kerr, S. R. 1971. Analysis of laboratory experiments on growth efficiency of fishes. Journal of Fisheries Research Board of Canada 28:801-808.

Kitchell, J. F., and J. E. Breck. 1980. Bioenergetics model and foraging hypothesis for sea lamprey (Pet- 
romyzon marinus). Canadian Journal of Fisheries and Aquatic Sciences 37:2159-2168.

Kitchell, J. F., D. J. Stewart, and D. Weininger. 1977. Applications of a bioenergetics model to yellow perch (Perca flavescens) and walleye (Stizostedion vitreum). Journal of the Fisheries Research Board of Canada 34:1922-1935.

Lane, E. D., M. C. S. Kingsley, and D. E. Thorton. 1979. Daily feeding and food conversion efficiency of the diamond turbot: an analysis based on field data. Transactions of the American Fisheries Society 108: 530-535.

Lawler, G. H. 1969. Activity periods of some fishes in Heming Lake, Canada. Joumal of the Fisheries Research Board of Canada 26:3266-3267.

Leggett, R. W., and C. R. Williams. 1981. A reliability index for models. Ecological Modelling 13:303-312.

Mann, R. H. K. 1978. Estimating food consumption of fish in nature. Pages 250-273 in S. D. Gerking, editor. Ecology of freshwater fish production. Wiley, New York.

Mauck, W. L., and D. W. Coble. 197I. Vulnerability of some fishes to northern pike (Esox lucius) predation. Journal of the Fisheries Research Board of Canada 28:957-969.

Minton, J. W., and R. B. McLean. 1982. Measurements of growth and consumption of sauger (Stizostedion canadense): implication for fish energetics studies. Canadian Journal of Fisheries and Aquatic Sciences 39:1 396-1403.

Nakashima, B. S., and W. C. Leggett. 1978. Daily ration of yellow perch (Perca flavescens) from Lake Memphremagog, Quebec-Vermont, with a comparison of methods for in situ determinations. Journal of the Fisheries Research Board of Canada 35: 1597-1603.

Neter, J., W. Wasserman, and M. H. Kutner. 1983. Applied linear regression models. Irwin, Homewood, Illinois.

Norstrom, R. J., A. E. McKinnon, and A. S. DeFreitas. 1976. A bioenergetics-based model for pollutant accumulation by fish. Simulation of PCB and methylmercury residue levels in Ottawa River yellow perch (Perca flavescens). Journal of the Fisheries Research Board of Canada 33:248-267.

Olson, R. J., and A. J. Mullen. 1986. Recent developments for making gastric evacuation and daily ration determinations. Environmental Biology of Fishes 16:183-191.

Paloheimo, J. E., and L. M. Dickie. 1966. Food and growth in fishes. III. Relations among food, body size, and growth efficiency. Journal of the Fisheries Research Board of Canada 23:1209-1249.

Pierce, R. J., T. E. Wissing, J. G. Jaworski, R. N. Givens, and B. A. Megrey. 1980. Energy storage and utilization patterns of gizzard shad in Acton Lake, Ohio. Transactions of the American Fisheries Society 109: 611-616.

Rice, J. A., J. E. Breck, S. M. Bartell, and J. F. Kitchell.
1983. Evaluating the constraints of temperature, activity, and consumption on growth of largemouth bass. Environmental Biology of Fishes 9:263-275.

Rice, J. A., and P. A. Cochran. 1984. Independent evaluation of a bioenergetics model for largemouth bass. Ecology 65:732-739.

SAS Institute. 1985. SAS user's guide: statistics, version 5 edition. SAS Institute, Cary, North Carolina.

Stewart, D. J., and F. P. Binkowski. 1986. Dynamics of consumption and food conversion by Lake Michigan alewives: an energetics-modeling synthesis. Transactions of the American Fisheries Society 115: 643-659.

Stewart, D. J., J. F. Kitchell, and L. B. Crowder. 1981. Forage fishes and their salmonid predators in Lake Michigan. Transactions of the American Fisheries Society 110:751-763.

Stewart, D. J., D. Weininger, D. V. Rottiers, and T. A. Edsall. 1983. An energetics model for lake trout, Salvelinus namaycush: application to the Lake Michigan population. Canadian Journal of Fisheries and Aquatic Sciences 40:681-698.

Strange, R. J., and J. C. Pelton. 1987. Nutrient content of clupeid forage fishes. Transactions of the American Fisheries Society 116:60-66.

Swenson, W. A., and L. L. Smith. 1973. Gastric digestion, food consumption, feeding periodicity, and food conversion efficiency in walleye (Stizostedion vitreum vitreum). Journal of the Fisheries Research Board of Canada 30:1327-1336.

Theil, H. 1961. Economic forecasting and policy. North Holland, Amsterdam.

Tomcko, C. M., R. A. Stein, and R. F. Carline. 1984. Predation by tiger muskellunge on bluegill: effects of predator experience, vegetation, and prey density. Transactions of the American Fisheries Society 113:588-594.

Wahl, D. H., and R. A. Stein. 1988. Selective predation by three esocids: the role of prey behavior and morphology. Transactions of the American Fisheries Society 117:142-151.

Wahl, D. H., and R. A. Stein. 1989a. Evaluation of stocking northern pike, muskellunge, and tiger muskellunge into Ohio lakes: a comparative approach. Ohio Department of Natural Resources, Federal Aid Project F-57-R, Final Report, Columbus.

Wahl, D. H., and R. A. Stein. 1989b. Comparative vulnerability of three esocids to largemouth bass (Micropterus salmoides) predation. Canadian Journal of Fisheries and Aquatic Sciences 46:2095-2103.

Warren, C. E. 1971. Biology and water pollution control. Saunders, Philadelphia.

Weithman, A. S., and R. O. Anderson. 1977. Survival, growth, and prey of Esocidae in experimental systems. Transactions of the American Fisheries Society $106: 424-430$.

Received September 21, 1988 Accepted July 26, 1990 